\title{
Trichomes With CRystals in the Cephalocereus Pfeiff.
}

\section{AREOLES}

\author{
María luisa Bárcenas-Argüello ${ }^{1,4}$, Teresa Terrazas² and Salvador Arias ${ }^{3}$ \\ 'Programa de Botánica, Colegio de Postgraduados, Montecillo, Estado de México, Mexico \\ ${ }^{2}$ Departamento de Botánica and ${ }^{3}$ Jardín Botánico, Instituto de Biología, Universidad Nacional Autónoma de México, \\ México D.F., Mexico \\ Corresponding author: marialuisabarcenas@gmail.com
}

\begin{abstract}
This research describes the trichomes produced in the old vegetative areoles of the five species of Cephalocereus Pfeiff. Light and scanning electron microscopy and energy dispersive X-ray analysis were used to characterize the crystals present in the stem vegetative areoles far from the apical meristem. We are reporting for the first time for the Cactaceae family capitated trichomes with crystals. Crystals had diverse shapes (prismatic, styloid, sandy) and they all contain $\mathrm{C}$ as their principal element, as well as $\mathrm{Na}, \mathrm{Cl}, \mathrm{Si}, \mathrm{Mg}, \mathrm{S}$, and $\mathrm{Ca}$ in different concentrations. Trichome and crystal characteristics allowed distinguishing the species of Cephalocereus. For example, capitate trichomes are shared by C.columna-trajani and C. senilis but differ because in $C$. columna-trajani there is one prismatic crystal per cell and sandy crystals in $C$. senilis. The other three species share non-capitated trichomes with prismatic crystals in the apical cell and styloids in the other cells. The species of Cephalocereus share the ontogenetic pathway of producing trichomes and spines in the areoles far from the apical meristem, suggesting that trichomes with crystals may be protecting the spines meristems.
\end{abstract}

Key words: biominerals, Cephalocereus apicicephalium, Cephalocereus columna-trajani, Cephalocereus nizandensis, EDAX, scanning electron microscopy.

Resumen: Esta investigación describe los tricomas de las areolas vegetativas de las cinco especies de Cephalocereus. La microscopía fotónica y electrónica de barrido, así como el análisis dispersivo de energía de rayos X, se utilizaron para caracterizar los cristales presentes en las areolas vegetativas de los tallos. Se reporta por primera vez para la familia Cactaceae tricomas capitados con cristales. Los cristales tuvieron diversas formas (prismas, estiloides, arena) y todos ellos contienen C como su elemento principal, así como $\mathrm{Na}, \mathrm{Cl}, \mathrm{Si}, \mathrm{Mg}, \mathrm{S}$ y Ca en diferentes concentraciones. Las características de los tricomas y de los cristales permitieron distinguir las especies de Cephalocereus. Por ejemplo, los tricomas capitados son compartidos por C. columna-trajani y $C$. senilis, pero se diferencian porque en $C$. columna-trajani hay un cristal prismático por célula y cristales de arena en $C$. senilis. Las otras tres especies comparten los tricomas no capitados con cristales prismáticos en la célula apical y estiloides en las otras células. Las especies de Cephalocereus comparten la vía ontogenética de producir tricomas y espinas en las areolas lejos del meristemo apical, lo que sugiere que los tricomas con cristales pueden estar protegiendo los meristemos.

Palabras clave: biominerales, Cephalocereus apicicephalium, Cephalocereus columna-trajani, Cephalocereus nizandensis, EDAX, microscopio electrónico de barrido.

C alcium oxalate crystals can be found in different plant organs and tissues (Franceschi and Horner, 1980; Franceschi and Nakata, 2005). Members of the Cactaceae family are not an exception, as crystals have been observed in the stems, roots, and flowers, mainly in the cells of the fundamental tissue (Terrazas and Mauseth, 2002; Hartl et al., 2007). Crystals have been documented in the hypodermis of Opuntia species (Conde, 1975; Monje and Baran, 2002; Tovar-Puente et al., 2007) and in wood the crystals are rare
(Gibson, 1973). There are also reports of crystals in stem epidermal cells of various genera of the subfamily Cactoideae, where they vary in shape and number. For example, the solitary prismatic crystals have been described in species of Acanthocereus, Armatocereus, and Peniocereus (Mauseth et al., 1998), the lenticular crystals in Lophocereus gatesii (Arias and Terrazas, 2006), and more than two prismatic crystals per cell in several species of Cephalocereus, Neobuxbaumia, and Pseudomitrocereus (Gibson and 
María Luisa Bárcenas-Argüello et al.

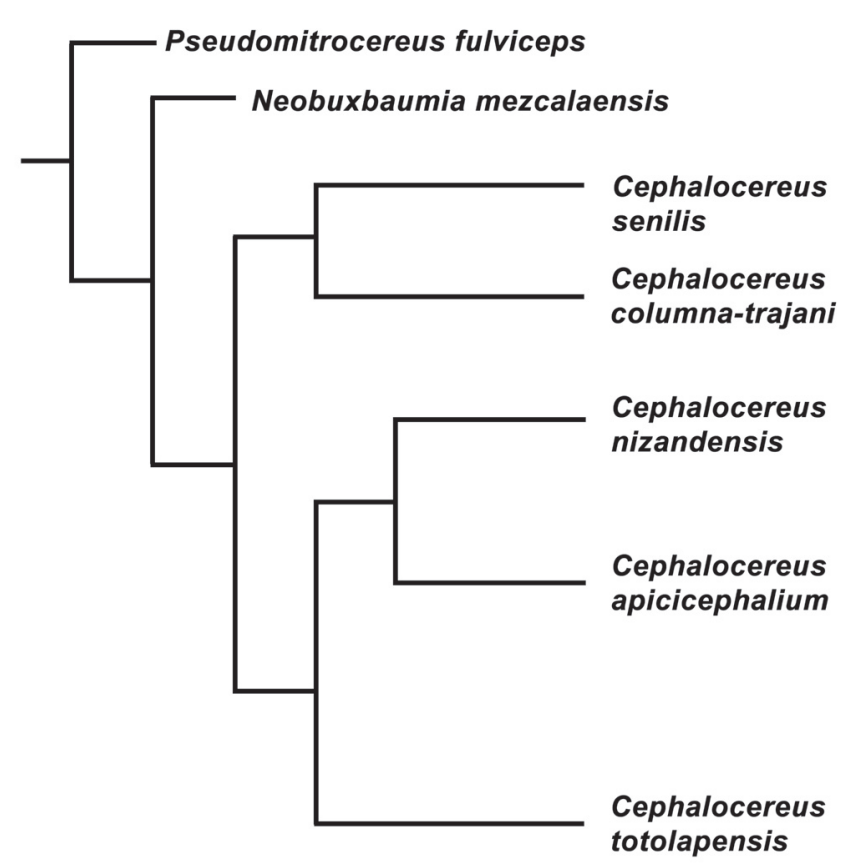

Figure 1. Phylogenetic relationships of Cephalocereus species (modified from Bárcenas-Argüiello, 2011).

Horak, 1978; Loza-Cornejo and Terrazas, 2003). Cheavin (1938) reported calcium oxalate crystals in C. senilis, with an abundance of up to $85 \%$ of dry matter weight. According to Hartl et al. (2007), in Cactaceae, the occurrence of crystals is not taxonomically informative. However, several authors mentioned that crystals support groups at different taxonomic levels. For example, the monophyly of the Cephalocereus-Neobuxbaumia-Pseudomitrocereus fulviceps clade is supported by the presence of prismatic crystals in the epidermis (Terrazas and Loza-Cornejo, 2002; Arias et al., 2003). Cephalocereus is a monophyletic genus of five species (Figure 1) endemic to Mexico with distinctive pseudocephalium or lateral cephalium, and producing trichomes in the old vegetative areoles. However, we do not know if trichomes in older areoles are similar to those described in the young areoles and if crystals are present also in these epidermal cells.

Trichomes may exhibit crystals; however, is not common and has only been observed in fifteen species of seven families, among them Araceae and Asteraceae (Table 1). In the Cactaceae, there have been no reports of crystals deposited in trichomes produced in the areola, except for VázquezSánchez et al. (2005), who found trichomes with crystals in the floral areoles of the lateral cephalium in Cephalocereus senilis. Based on this observation, one question was if the Cephalocereus species will have crystals in the trichomes of their old vegetative areoles. Several studies mention the importance of the trichomes in this family. Arreola-Nava (2000) indicates that a clade of seven species of Stenocereus is supported by the presence of glandular trichomes in the
Table 1. Distribution of crystals in trichomes in angiosperms.

\begin{tabular}{|c|c|c|c|}
\hline Species (Family) & $\begin{array}{l}\text { Type of } \\
\text { crystal }\end{array}$ & Organ & Authors \\
\hline $\begin{array}{l}\text { Xanthosoma sagittifolium } \\
\text { (Araceae) }\end{array}$ & raphide & $\begin{array}{l}\text { leaf } \\
\text { (petiole) }\end{array}$ & $\begin{array}{l}\text { Sakai et al., } \\
1972\end{array}$ \\
\hline Cocos (Arecaceae) & raphide & & Frey, 1929 \\
\hline $\begin{array}{l}\text { Jubaeopsis caffra } \\
\text { (Arecaceae) }\end{array}$ & raphide & $\begin{array}{l}\text { flower } \\
\text { (petals) }\end{array}$ & $\begin{array}{l}\text { Robertson, } \\
1978\end{array}$ \\
\hline $\begin{array}{l}\text { Justicia betonica, } \\
\text { Hygrophyla auriculata } \\
\text { (Acanthaceae) }\end{array}$ & $\begin{array}{l}\text { needle-like, } \\
\text { rodlike, } \\
\text { square, } \\
\text { prismatic }\end{array}$ & leaf & $\begin{array}{l}\text { Inamdar, } \\
1970\end{array}$ \\
\hline $\begin{array}{l}\text { Nassauvia aculeata, } \\
\text { N. axilaris, N. chubutensis, } \\
\text { N. darwini, N. fuegiana, } \\
\text { N. glomerulosa, N. ulicina, } \\
\text { N. uniflora (Asteraceae) }\end{array}$ & $\begin{array}{l}\text { prismatic, } \\
\text { lenticular }\end{array}$ & leaf & $\begin{array}{l}\text { Ragonese, } \\
1987\end{array}$ \\
\hline $\begin{array}{l}\text { Eremophila fraseri } \\
\text { (Myoporaceae) }\end{array}$ & raphides & leaf & $\begin{array}{l}\text { Dell and } \\
\text { McComb, } \\
1977\end{array}$ \\
\hline $\begin{array}{l}\text { Conanthera campanulata } \\
\text { (Tecophilaeaceae) }\end{array}$ & raphide & $\begin{array}{l}\text { flower } \\
\text { (tepals) }\end{array}$ & $\begin{array}{l}\text { Prychid and } \\
\text { Rudall, } 1999\end{array}$ \\
\hline
\end{tabular}

areoles; likewise, Arias and Terrazas (2006), in their study of the genus Pachycereus mention a group of ten species, all of which show abundant trichomes in the pericarpel and floral tube areoles. The areola is a complex region unique to members of the Cactaceae family. In this region, an axillary meristem, axillary buds or short shoot can be found, which are commonly active for a long time, or only one year or two and may be either vegetative or reproductive or both (Boke, 1944, 1951). Areoles produce uniseriate multicellular trichomes giving a woolly appearance with or without spines (Boke, 1944; Terrazas and Mauseth, 2002) developing as early as the first primordium differentiates in the flacks of the areole meristem (Boke, 1951). In this paper, we describe and compare the trichomes of the old vegetative areoles in the five species of Cephalocereus sensu Anderson (2001), including their shape and their mineral contents; as well as a discussion of their possible function.

\section{Material and methods}

Between five and ten active vegetative areoles were collected from the middle region of the branches in three to six individuals per species of Cephalocereus (Table 2). Since no evidence of trichomes was observed in the middle region of the stems of Neobuxbaumia and Pseudomitrocereus, in comparison with those of Cephalocereus species, their areoles were not collected (Figure 2). The areoles were fixed 


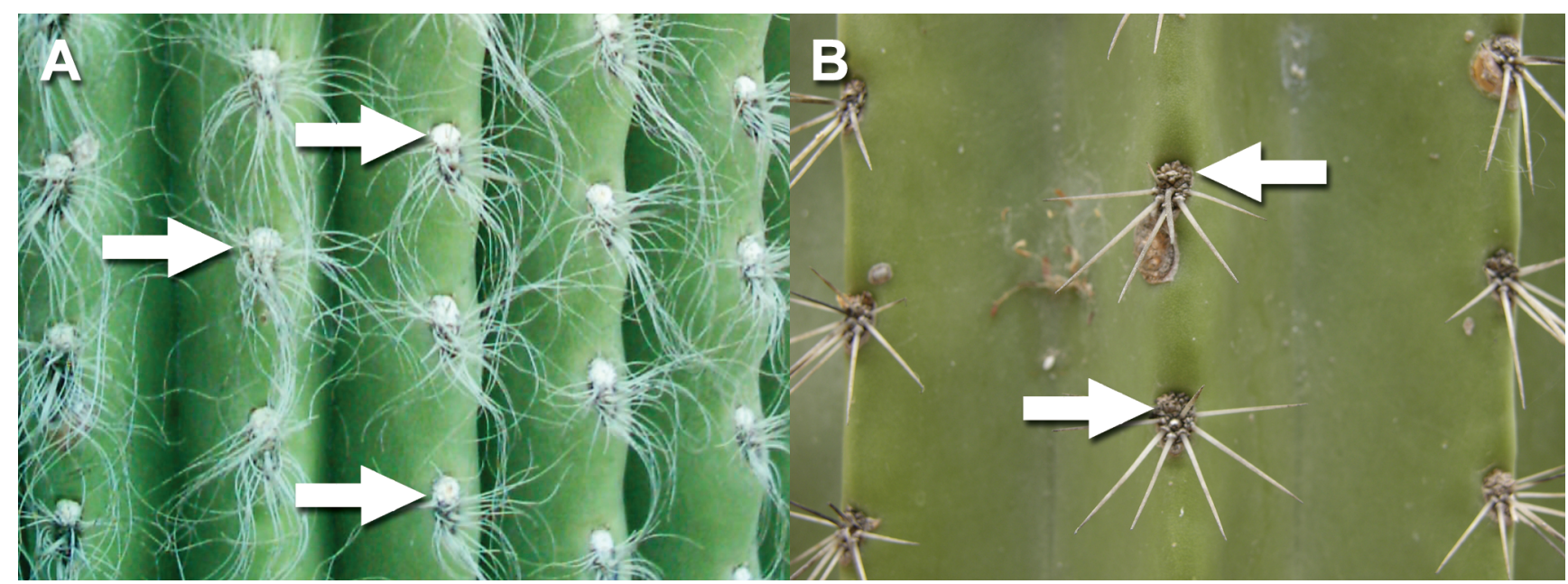

Figure 2. Areoles of the middle stem of Cephalocereus senilis (A) and Neobuxbaumia mezcalaensis (B), showing active meristems (arrows) or inactive meristems (arrow).

in formaldehyde-acetic acid-ethanol (Johansen, 1940). In the laboratory, they were stored in glycerin-ethanol-water $(1: 1: 1)$ until they were studied. The areoles were observed under a stereoscopic microscope and the trichomes were separated with a needle. The complete and turgid ones were selected, placed on slides and mounted with water for immediate observation performed with an image analyzer Image-Pro-Plus, version 3.1 (Media Cybernetics, 1997) using a video camera Hitachi KPD51 and an Olympus BX50 microscope with polarized system. Also wall thickness of apical trichome cells was quantified and trichome number of cells counted. Crystal morphology follows Franceschi and Horner (1980).

For scanning electron microscopy (SEM), the areoles were also dehydrated, cleaned with ultrasound (Cole-Parmer 8851) and critical-point dried (Samdri-780a). Dry samples were fixed to aluminium specimen holders with double-sided conductive carbon tape and coated with gold in a JEOL-JFC-1100 sputter coater. Morphological obser-

Table 2. List of taxa investigated in this study. All voucher collections are T. Terrazas, vouchers deposited at CHAPA. *Specimen used in SEM.

\begin{tabular}{ll}
\hline \multicolumn{1}{c}{ Species } & \multicolumn{1}{c}{ State and collection number } \\
\hline C. apicicephalium E.Y.Dawson & $\begin{array}{l}\text { Oaxaca 508, 512, 509, 513, } \\
704 *, 711\end{array}$ \\
$\begin{array}{l}\text { C. columna-trajani (Karw. } \\
\text { Ex Pfeiff) K.Schum. }\end{array}$ & $\begin{array}{l}\text { Puebla, Oaxaca 443, 444, } \\
681^{*}, 690\end{array}$ \\
$\begin{array}{l}\text { C. nizandensis (Bravo \& } \\
\text { T.MacDoug.) Buxb. }\end{array}$ & Oaxaca 699, 700*, 703 \\
$\begin{array}{l}\text { C. senilis (Haworth) Pfeiff. } \\
\text { C. totolapensis (Bravo \& }\end{array}$ & Hidalgo 640*, 930 \\
T.MacDoug.) Buxb. & Oaxaca 516, 572, 574*, 628 \\
\hline
\end{tabular}

vations and photographs were carried out in a JEOL JSM35C. In addition, the trichomes of two species (Cephalocereus columna-trajani and $C$. nizandensis) were fragmented. We studied only these two species based on Cephalocereus cladogram (Figure 1), arguing that other members of each clade will share the same traits. The fragments, in distilled water, were centrifuged in a Beckman TJ-6 at 1,000 rpm for $5 \mathrm{~min}$ and the supernatant was discarded with a pipette. Drops from the liquid were placed on slides and left to dry. Once dried, the crystals were removed toward the sample holders with a brush for evaluation using an energy dispersive X-ray microanalysis (EDAX) with a JEOL6300.

\section{Results}

Trichome description. The five species of Cephalocereus showed uniseriate, multicellular capitated and non-capitated trichomes (Figures 3,4), and they are common in the old areoles in the middle and basal part of the stems, but never present in Neobuxbaumia (Figure 2) and Pseudomitrocereus. The non-capitated are large ( $>30$ cells per trichome) and all the cells are of equal size and equal wall-thickness. The capitated trichomes have less than 20 cells long per trichome in four of the species, and more than 20 cells in C. senilis. The number of apical cells that expand varies among the species, in C. columna-trajani, C. senilis and C.totolapensis it is three to five cells (Figures 3B-D, 4A-C), while in $C$. nizandensis and C.apicicephalium it is only one cell (Figure $3 \mathrm{~A}, \mathrm{E})$. However, in C. apicicephalium cell expansion is so slight that it is only observed when these trichomes are compared to non-capitated ones, which have very thin and large cells (Figure 3E). The apical cells acquire different shapes, in $C$. columna-trajani and $C$. senilis they are round (Figure 3D, F), and in C.apicicephalium, C.totolapensis and C.nizandensis they are apiculate (Figure 3A, C, G). Apical cells 


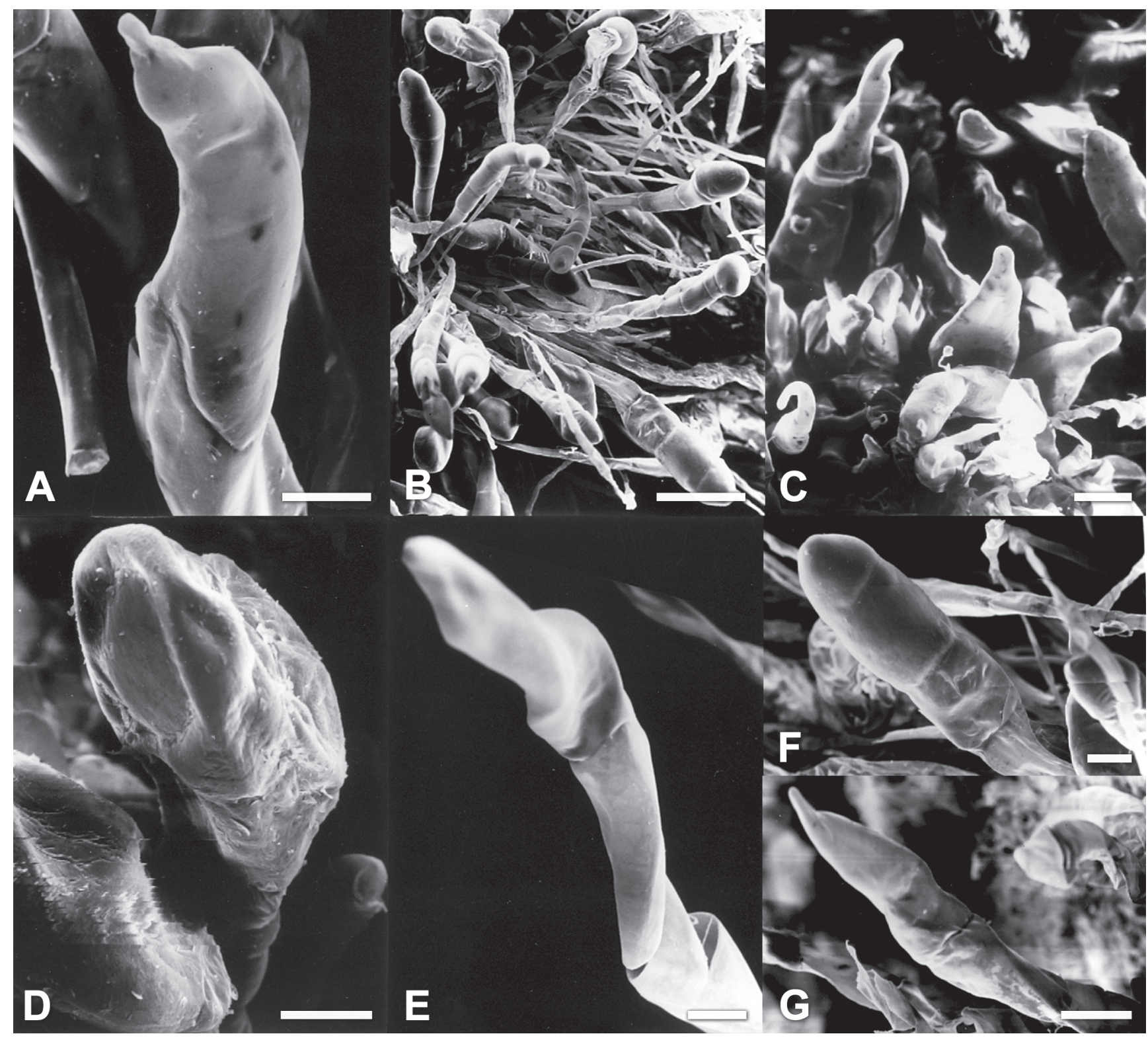

Figure 3. Trichomes in Cephalocereus species. A. C. nizandensis (Terrazas 700). B. C. columna-trajani (Terrazas 681). C. C.totolapensis (Terrazas 574). D. C. senilis (Terrazas 640). E. C.apicicephalium (Terrazas 704). F. C. columna-trajani (Terrazas 681). G. C. nizandensis (Terrazas 700). Scale $50 \mu \mathrm{m}$.

wall thickness varies from $1.68 \pm 0.08 \mu \mathrm{m}$ thick in C. apicicephalium to $3.18 \pm 0.17 \mu \mathrm{m}$ thick in C. senilis (Table 3). The trichome cells remain alive with cytoplasm and nucleus, the latter more evident in trichome basal cells. Also dark contents in different proportions were observed; in C. columna-trajani these contents were reddish-brown and moderately abundant, while in $C$. totolapensis contents were orange and very abundant, in C. nizandensis they were greenish-yellow and scarce, and absent in the two remaining species.

Crystal description. The crystals were found in the cells of both types of trichomes, near the walls of adjacent cells, apparently in the vacuole. In the cells of capitated trichomes, prismatic, styloid, and sandy crystals were observed, with one to more-than- five crystals per cell (Table 4, Figure 4). For example, in Cephalocereus columna-trajani, it is common to observe only one prismatic crystal per cell (Figure 4D, E); and in C. senilis, sandy crystals occurred in every cell (Figure 4F). In C.apicicephalium, C. nizandensis and $C$. totolapensis, several prismatic crystals can be seen in apical cells and in the other cells exclusively styloids (Figure 4G-J). In C. columna-trajani and C. nizandensis, for which crystal biomineral composition was evaluated, we found that both prismatic and styloid crystals contained $\mathrm{C}, \mathrm{Na}, \mathrm{Cl}$, and $\mathrm{O}$, 
Table 3. Wall thickness (mean \pm standard error) of the apical cell of the capitated trichomes present in the vegetative areolae in Cephalocereus. Different letters indicate statistical differences (Tukey, $P<0.05$ ).

\begin{tabular}{ll}
\hline Species & Thickness $(\mu \mathrm{m})$ \\
\hline C. apicicephalium & $1.68 \pm 0.08^{\mathrm{a}}$ \\
C. columna-trajani & $2.81 \pm 0.16^{\mathrm{b}}$ \\
C. nizandensis & $1.77 \pm 0.09^{\mathrm{a}}$ \\
C. senilis & $3.18 \pm 0.17^{\mathrm{b}}$ \\
C. totolapensis & $1.77 \pm 0.08^{\mathrm{a}}$ \\
\hline
\end{tabular}

as well as traces of $\mathrm{Si}$ and $\mathrm{Ca}$ in their mineral composition (Figure 5A), while they were more diverse in C. columnatrajani, containing $\mathrm{O}, \mathrm{Si}, \mathrm{C}, \mathrm{Na}, \mathrm{Ca}, \mathrm{Mg}, \mathrm{Cl}$, and traces of $\mathrm{K}$ and $\mathrm{S}$ in their composition (Figure $5 \mathrm{~B}$ ).

\section{Discussion}

Trichomes in the Cactaceae family have been mostly studied in developing areoles near the apical meristem (Gibson and Nobel, 1986; Arreola-Nava, 2000). Other authors indicate

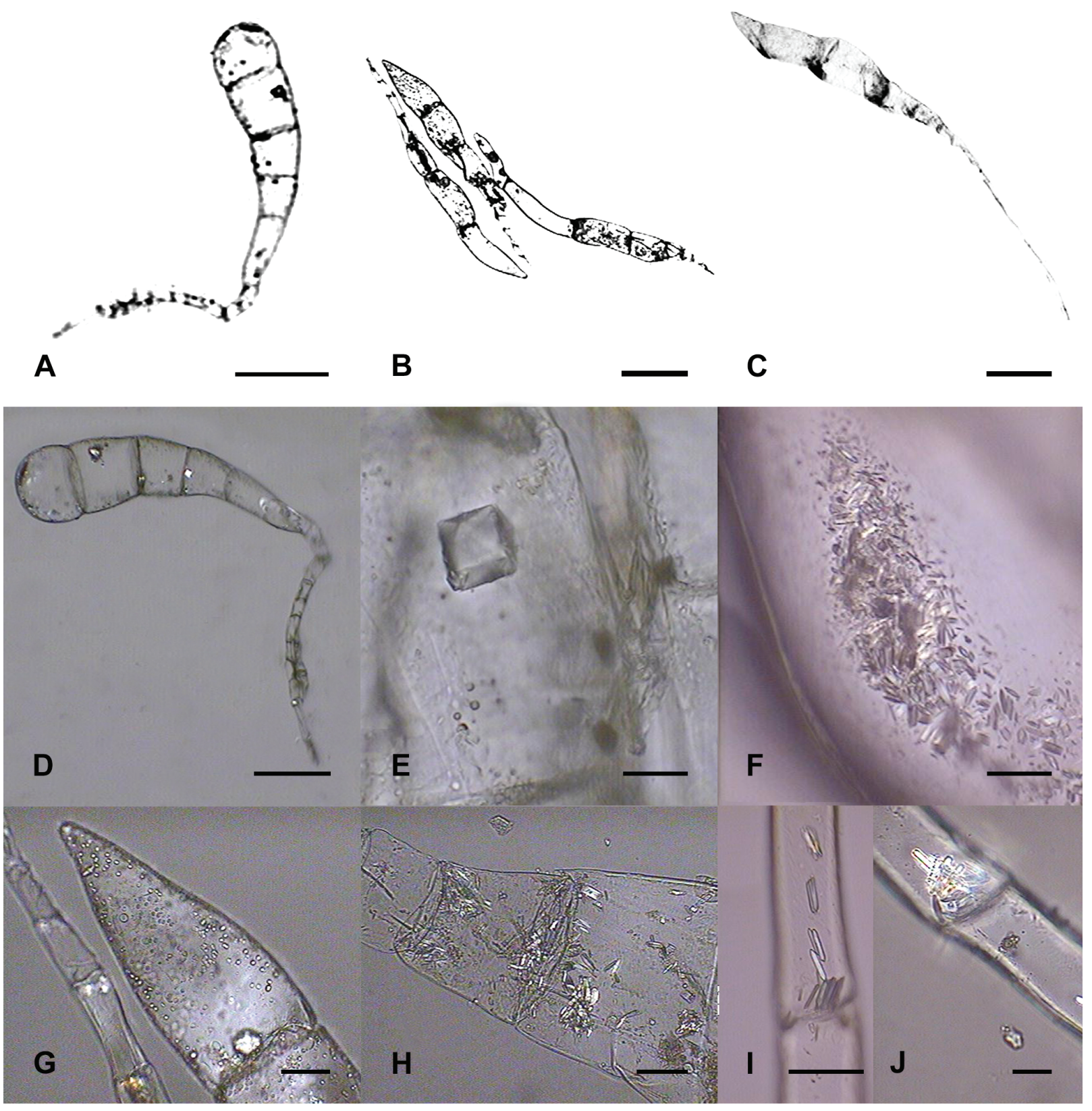

Figure 4. Number of apical cells and crystals in trichomes Cephalocereus species. A, D-E. C. columna-trajani (Terrazas 681). B, G-H. C. totolapensis (Terrazas 516). C, F. C. senilis (Terrazas 640). I. C. apicicephalium (Terrazas 508). J. C. nizandensis (Terrazas 703). Scales $\mathrm{A}=350 \mu \mathrm{m} ; \mathrm{B}, \mathrm{C}=300 \mu \mathrm{m} ; \mathrm{D}=150 \mu \mathrm{m} ; \mathrm{E}, \mathrm{J}=20 \mu \mathrm{m} ; \mathrm{F}-\mathrm{H}=50 \mu \mathrm{m}$. 
Table 4. Characteristics of cells and crystals in the capitated trichomes of the old vegetative areoles in Cephalocereus, Neobuxbaumia mezcalaensis and Pseudomitrocereus fulviceps. - = lacking.

\begin{tabular}{|c|c|c|c|c|}
\hline Species & $\begin{array}{l}\text { Apical } \\
\text { cel shape }\end{array}$ & $\begin{array}{c}\text { Number } \\
\text { of wider } \\
\text { apical } \\
\text { cells }\end{array}$ & $\begin{array}{c}\text { Crystal } \\
\text { types in } \\
\text { the apical } \\
\text { cell }\end{array}$ & $\begin{array}{c}\text { Cyrstal } \\
\text { types in } \\
\text { the foot } \\
\text { cells }\end{array}$ \\
\hline C. nizandensis & apiculate & one & prismatic & styloids \\
\hline C. apicicephalium & apiculate & one & prismatic & styloids \\
\hline C. totolapensis & apiculate & $3-5$ & prismatic & styloids \\
\hline C. columna-trajani & botuliforme & $3-5$ & prismatic & prismatic \\
\hline C. senilis & botuliforme & $3-5$ & sandy & sandy \\
\hline $\begin{array}{l}\text { Neobuxbaumia } \\
\text { mezcalaensis }\end{array}$ & - & & & \\
\hline $\begin{array}{l}\text { Pseudomitrocereus } \\
\text { fulviceps }\end{array}$ & - & & & \\
\hline
\end{tabular}

that areoles located in branches far from the apical meristem lose their trichomes and are usually inactive (Benson, 1982). This is not the case in Cephalocereus, whose species display the presence of uniseriate, multicellular, capitated
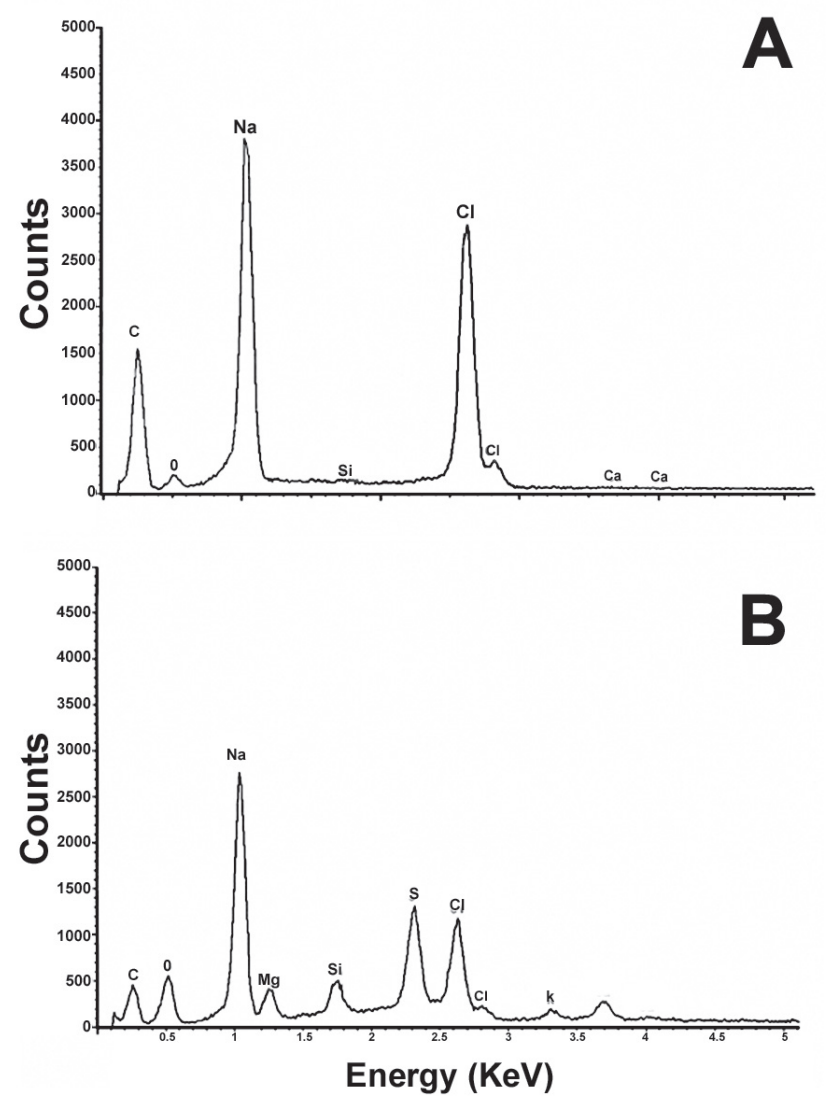

Figure 5. EDAX spectra on the isolated biominerals from trichomes. A. C. nizandensis (Terrazas 681). B. C. columna-trajani (Terrazas 699). and non-capitated trichomes with crystals in the areoles far from the apical meristem. The ability of Cephalocereus to produce these trichomes contrasts with their sister taxa Neobuxbaumia and Pseudomitrocereus that do not have them.

The shape, number, and distribution of crystals within the plant's body may be distinctive for certain species (Wu and Kuo-Huang, 1997; Prychid and Rudall, 1999; Lersten and Horner, 2008). In the Cactaceae family, crystals have contributed to the delimitation of subfamilies and genera; for example, Conde (1975) mentions that druses located in the Opuntia hypodermis define the Opuntioideae subfamily, an asseveration supported by their type of biominerals present (Monje and Baran, 2002). Calcium oxalate monohydrate crystals located in epidermal or cortical cells distinguish species of the Rhipsalis genus, while calcium oxalate dihydrate crystals characterize species of the Lepismium, Hatioria, and Schlumbergera genera (Hartl et al., 2003). Terrazas and LozaCornejo (2002) found prismatic crystals in the epidermis of the species of Neobuxbaumia, Cephalocereus, and Pseudomitrocereus. Thus, the diversity of crystal number in trichome cells of the Cephalocereus species is not surprising.

The presence of crystals in the trichomes is not very common, though it has been observed in leaves (Inamdar, 1970; Ragonese, 1987), petioles (Sakai et al., 1972), tepals (Prychid and Rudall, 1999), and petals (Robertson, 1978) of different plant families. The type of crystals located in trichomes may be raphide (Inamdar, 1970; Sakai et al., 1972; Robertson, 1978; Prychid and Rudall, 1999), prismatic, and lenticular (Ragonese, 1987). In this study, we describe for the first time crystals present in trichomes of the vegetative areoles of Cephalocereus species. Moreover, their shapes were more diverse than those reported in stem epidermal cells, limited only to prismatic crystals. VázquezSánchez et al. (2005) mention the presence of small crystals in trichomes of floral areoles in the cephalium of $C$. senilis. Our observations confirm the occurrence of crystals in the vegetative areoles in the stem of the five species.

Various functional explanations have been given to the occurrence of calcium oxalate crystals in plant tissue; e.g. to protect against damage caused by small animals (Conde, 1975; Franceschi and Nakata, 2005), because if those tissues are eaten, they cause irritation (Prychid and Rudall, 1999). They may also serve as an attraction for pollen spreading biological agents (Robertson, 1978). In addition, the sodium chloride crystals that accumulate on the leaf surface can increase reflectivity, protecting the epidermis against excessive light (Uchiyama and Sugimura, 1985; Karimi and Ungar, 1989; Rajput and Sen, 1991), which may explain the presence of $\mathrm{Na}$ and $\mathrm{Cl}$ in the crystals deposited in the trichomes that protect the areola meristems in species of Cephalocereus. Furthermore, several authors (Conde, 1975; Darling, 1989) point out that the crystals help to reduce evaporation or increase reflectivity, as well as to decrease transmittance. This may occur in the five species of Cephalocereus; growing in 
regions where diurnal temperature exceeds $40{ }^{\circ} \mathrm{C}$ and the crystals may contribute to protect the young tissues located in the areoles by reducing the temperature. It is outstanding that the biominerals present in the trichomes of the two studied species of Cephalocereus, as well as those found in the ordinary epidermal cells of three species of Cephalocereus (Bárcenas-Argüello et al., 2010) are more diverse than those reported for other Cactaceae species (Rivera and Smith, 1979; Monje and Baran, 2002). Bárcenas-Argüello (2011) have demonstrated that the availability of these minerals in the soil and their occurrence in stem of five species Cephalocereus is not related, further studies are needed to understand their metabolic development.

Trichome morphology has been used as an important attribute in the classification of genera and species (Heintzelman and Howard, 1948; Inamdar, 1970; Valencia and Delgado, 2003; Batterman and Lammers, 2004), and for the identification of interspecific hybrids (Rollins, 1944). Hardin (1979) indicates that trichome morphology is commonly not affected by the environment, and therefore, may contribute to understanding the phylogenetic relations of different plant groups. Trichomes can display a wide variation within a family or can be quite uniform; they are also different depending on the organ that is being studied (Rao and Ramayya, 1977; Cosa et al., 2002). In the Cactaceae family, papillose surfaces have been described in species of the Cactoideae subfamily (see Terrazas and Arias, 2002). However, the presence of trichomes has been restricted to epidermal derivatives associated with the areoles. Gibson y Nobel (1986) describe the ontogeny of these simple multicellular trichomes and, with the exception of the glandular trichomes reported by Arreola-Nava (2000) for the seven species of Stenocereus, apical cells have been described as a triangular shape, and so the capitated trichomes described herein for Cephalocereus are unique. Both shape and number of cells that expand in the apical region of the trichomes characterize the Cephalocereus species (Table 4).

The species Cephalocereus apicicephalium, C. nizandensis, and C.totolapensis have apical capitated trichomes with prismatic crystals and in the other trichome cells styloid crystals. The rounded capitated trichomes allow us to recognize $C$. columna-trajani and $C$. senilis, though the first is distinguished by its brown contents and prismatic crystals in all of the trichome cells and the second is characterized by the presence of sandy crystals.

In conclusion, the morphological differences in crystals and trichomes developed in the old areoles in the five species of Cephalocereus allow distinguishing among them and from their sister taxa (Neobuxbaumia and Pseudomitrocereus). In addition, the five species of Cephalocereus share the ontogenetic pathway of producing trichomes and spines in the areoles far from the apical meristem. These trichomes together with crystals constitute a high-specialization characteristic that protects the meristems located in the areoles.

\section{Acknowledgements}

This study was supported by Consejo Nacional de Ciencia y Tecnología (CONACYT) grant 33064-V (T.T.), the senior author also thanks CONACYT scholarship (47318) to perform graduate studies. We also appreciate the collaboration of the authorities of Meztitlán Biosphere Reserve and SEMARNAT, which allow us to recollect material for this study, to Ana Bertha Soto, CINVESTAV-IPN for EDAX analyses, to Rosa María Picaso for scanning electron microscopy technical assistance at Colegio de Postgraduados, and two anonymous reviewers which help to clarify some ideas.

\section{Literature cited}

Anderson E.F. 2001. The Cactus Family. Timber Press, Portland. Arias S. and Terrazas T. 2006. Análisis cladístico del género $\mathrm{Pa}$ chycereus (Cactaceae) con caracteres morfológicos. Brittonia 58:197-216.

Arias S., Terrazas T. and Cameron K. 2003. Phylogenetic analysis of Pachycereus (Cactaceae, Pachycereeae) based on chloroplast and nuclear DNA sequences. Systematic Botany 28:547-557.

Arreola-Nava H.J. 2000. Sistemática de las especies de Stenocereus (A. Berger) Riccob. con aréolas morenas (Cactoideae: Cactaceae). Tesis de Maestría, Colegio de Postgraduados, Montecillo. 103 pp.

Bárcenas-Argüello M.L. 2011. Distribución ecológica del subgénero Neodawsonia Backeb. del género Cephalocereus Pfeiff. (Cactaceae), en el Istmo de Tehuantepec, México. Tesis Doctoral. Programa de Botánica, Colegio de Postgraduados, Montecillo. 93 pp.

Bárcenas-Argüello M.L., Gutiérrez-Castorena M.C., Terrazas T. and López-Mata L. 2010. Rock-soil preferences of three $\mathrm{Ce}$ phalocereus (Cactaceae) species of tropical dry forests. Soil Science Society of America Journal 74:1374-1382.

Batterman M.R.W. and Lammers T.G. 2004. Branched foliar trichomes of Lobelioideae (Campanulaceae) and the infrageneric classification of Centropogon. Systematic Botany 29:448-458.

Benson L. 1982. The Cacti of the United States and Canada. Stanford University Press, Palo Alto.

Boke N.H. 1944. Histogenesis of the leaf and areole in Opuntia cylindrica. American Journal of Botany 31:299-316.

Boke N.H. 1951. Histogenesis of the vegetative shoot in Echinocereus. American Journal of Botany 38:23-38.

Cheavin W.H.S. 1938. The crystals and cystoliths found in plant cells. Part I. Crystals. Microscope 2:155-158.

Conde L.F. 1975. Anatomical comparisons of five species of Opuntia (Cactaceae). Annals of Missouri Botanical Garden 62:425-473.

Cosa M.T., Hadid M., Dottoti N. and Bruno G. 2002. Anatomía de órganos vegetativos en Solanum palinacanthum, S. sisymbriifolium y S. euacanthum (Solanaceae). Anales del Instituto de Biología, Universidad Nacional Autónoma de México, Serie Botánica 73:27-38.

Darling M.S. 1989. Epidermis and hypodermis of the saguaro cactus (Cereus giganteus): anatomy and spectral properties. American Journal of Botany 76:1698-1706.

Dell B. and McComb A.J. 1977. Glandular hair formation and re- 
sin secretion in Eremophila fraseri F. Meull (Myoporaceae). Protoplasma 92:71-86.

Franceschi V.R. and Horner H.T. 1980. Calcium oxalate crystals in plants. The Botanical Review 46:361-427.

Franceschi V.R. and Nakata P.A. 2005. Calcium oxalate in plants: Formation and function. Annual Review of Plant Biology 56:41-71

Frey A. 1929. Calciumoxalat-monohydrat und trihydrat. In: Linsbauer K. Ed. Handbuch der Pflanzenanatomie, pp. 82-127, Gebrüder Bornträger, Berlin.

Gibson A.C. 1973. Comparative anatomy of secondary xylem in Cactoideae (Cactaceae). Biotropica 5:29-65.

Gibson A.C. and Horak K.E. 1978. Systematic anatomy and phylogeny of Mexican columnar cacti. Annals of the Missouri Botanical Garden 65:999-1057.

Gibson A.C. and Nobel P.S. 1986. The Cactus Primer. Harvard University Press, Cambridge.

Hardin J.W. 1979. Patterns of variation in foliar trichomes of Eastern North American Quercus. American Journal of Botany 66:576-585.

Hartl W.P., Barbier B., Klapper H., Müller P. and Barthlott W. 2003. Dimorphism of calcium oxalate crystals in stem tissues of Rhipsalideae (Cactaceae) - a contribution to the systematics and taxonomy of the tribe. Botanische Jahrbücher für Systematik 124:287-302.

Hartl W.P., Klapper H., Barbier B., Ensikat H.J., Dronskowski R., Müller P., Ostendorp G., Tye A., Bauer R. and Barthlott W. 2007. Diversity of calcium oxalate crystals in Cactaceae. Canadian Journal of Botany 85:501-517.

Heintzelman C.E. Jr. and Howard R.A. 1948. The comparative morphology of the Icacinaceae. V. The pubescence and the crystals. American Journal of Botany 35:42-52.

Inamdar J.A. 1970. Epidermal structure and ontogeny of caryophyllaceous stomata in some Acanthaceae. Botanical Gazzete 131:261-268.

Johansen D.A. 1940. Plant Microtechnique. MacGraw-Hill, New York.

Karimi S.H. and Ungar I.A. 1989. Development of epidermal salt hairs in Atriplex triangularis Willd. in response to salinity, light intensity, and aeration. Botanical Gazzete 150:68-71.

Lersten N.R. and Horner H.T. 2008. Crystal macropatterns in leaves of Fagaceae and Nothofagaceae: a comparative study. Plant Systematics and Evolution 271:239-253.

Loza-Cornejo S. and Terrazas T. 2003. Epidermal and hypodermal characteristics in North American Cactoideae (Cactaceae). Journal of Plant Research 116:27-35.

Mauseth J.D., Terrazas T. and Loza-Cornejo S. 1998. Anatomy of relictual members of subfamily Cactoideae IOS group 1a (Cactaceae). Bradleya 16:31-43.

Media Cybernetics. 1997. Image Pro Plus, Reference Guide. Version 3.1 for Windows. Silver Spring, Maryland.

Monje P.V. and Baran E.J. 2002. Characterization of calcium oxalates generated as biominerals in cacti. Plant Physiology 128:707-713.
Prychid C.J. and Rudall P.J. 1999. Calcium oxalate crystals in monocotyledons: A review of their structure and systematics. Annals of Botany 84:725-739.

Ragonese A.M. 1987. La presencia de cristales en los pelos de varias especies de Nassauvia (Compositae). Darwiniana 28:245250.

Rajput P. and Sen D.N. 1991. Salt bladders in Atriplex spp. Annals of Arid Zone 30:347-351.

Rao S.R.S and Ramayya N. 1977. Structure, distribution and taxonomic importance of trichomes in the Indian species of Malvastrum. Phytomorphology 27:40-44.

Rivera E.R. and Smith B.N. 1979. Crystal morphology and ${ }^{13}$ carbon $/{ }^{12}$ carbon composition of solid oxalate in cacti. Plant Physiology 64:966-970.

Robertson B.L. 1978. Raphide-sacs as epidermal appendages in Jubaeopsis caffra Becc. (Palmae). Annals of Botany 42:489490.

Rollins R.C. 1944. Evidence for natural hybridity between guayule (Parthenium argentatum) and mariola (Parthenium incanum). American Journal of Botany 31:93-99.

Sakai W.S., Hanson M. and Jones R.C. 1972. Raphides with barbs and grooves in Xanthosoma sagittifolium (Araceae). Science 178:314-315.

Terrazas T. and Arias S. 2002. Comparative stem anatomy in the subfamily Cactoideae. The Botanical Review 68:444-473.

Terrazas T. and Loza-Cornejo S. 2002. Phylogenetic relationships of Pachycereeae: A cladistic analysis based on anatomicalmorphological data. In: Fleming T.H. and Valiente-Banuet A. Eds. Columnar Cacti and their Mutualists: Evolution, Ecology, and Conservation, pp. 66-86, The University of Arizona Press, Tucson.

Terrazas S.T. and Mauseth J.D. 2002. Shoot anatomy and morphology. In: Nobel P.S. Ed. Cacti. Biology and Uses, pp. 23-40, University of California Press, Berkeley.

Tovar-Puente A., Pando-Moreno M., González-Rodríguez H., Scott-Morales L. and Méndez-Gallegos S.J. 2007. Densidad de cristales de oxalato de calcio en quince cultivares de nopal. Journal of the Professional Association for Cactus Development 9:91-98.

Uchiyama Y. and Sugimura Y. 1985. Salt-excreting function of vesiculated hairs of Atriplex nummularia. Japanese Journal of Crop Science 54:39-46.

Valencia A.S. and Delgado S.A. 2003. Los tricomas foliares en la caracterización de un grupo de especies del género Quercus sección Lobatae (Fagaceae). Anales del Instituto de Biología, Universidad Nacional Autónoma de México, Serie Botánica 74:5-15.

Vázquez-Sánchez M., Terrazas T. and Arias S. 2005. Morfología y anatomía del cefalio de Cephalocereus senilis (Cactaceae). Anales del Jardín Botánico de Madrid 62:153-161.

Wu C.C. and Kuo-Huang L.L. 1997. Calcium crystals in the leaves of some species of Moraceae. Botanical Bulletin of Academia Sinica 38:97-104.

Associated editor: Silvia Aguilar-Rodríguez

Received: August 8th, 2013

Accepted: November 12th, 2013

342

Botanical Sciences 92 (3): 335-342, 2014 